\title{
Effects of Classical Music Therapy on Anxiety Level of Caesarean Section Mother
}

\author{
Sumarni Marwang ${ }^{1}$, Rosita Passe ${ }^{1}$, Rosdianah Aswan ${ }^{1}$, Nurhidayat Triananinsi ${ }^{1}$, Nahira Iskandar ${ }^{1}$, \\ Fadjriah Ohorella $^{1}$, Sumarni Sikki ${ }^{1}$ \\ ${ }^{l}$ Midwifery Study Program, Mega Rezky University
}

\begin{abstract}
Caesarean delivery will cause mother to experience anxiety. It can cause interference to the physiological processes in the body. This research aims to find effectiveness of classical music therapy on anxiety level of casarean section mother at Syekh Yusuf Regional General Hospital, Gowa district, by using Hamilton Rating Scale (HARS). This research was an experimental research with a pre-experimental design of one group pre-test and post-test design. The sample was 30 caesarean mothers who met the criteria.

Based on the results of Wilcoxon rank statistical analysis test, $p$ value $=0,000$ and smaller than the $\alpha$ value determined at 0.05 . Therefore, it can be concluded that classical music therapy is effective to reduce anxiety level of caesarean mothers.
\end{abstract}

Key words: Classical music, anxiety, casarean section

\section{Introduction}

Childbirth is a process of expelling the product of conception from the uterus through the vagina to the outside world. Maternal Mortality Rate (MMR) in Indonesia has not yet reached 102 per 100,000 live births. According to data from 2012 Indonesian Health Demographic Survey (IDHS), Maternal Mortality Rate (MMR) in Indonesia is around 359 per 100,000 live births, an increase compared to 2007 with 228 per 100,000 live births. Although global intervention urges that the development to Millennium Development Goals (MDGs) in 2015 is below the achievement target.1,2

World Health Organization (WHO) sets standard rate for caesarean section in a country is around $10-15 \%$ per 1,000 births in the world. According to WHO, the increasing rate in sectio caesarea childbirth among many countries all over Asia reaches 110,000 during 2007-2008. In Indonesia the incidence of caesarean increased in 2000 by $47.22 \%$, in 2001 by $45.19 \%$, in 2002 by $47.13 \%$, in by $46.87 \%$, in 2004 by $53.2 \%$, in 2005 by $51.59 \%$, and in 2006 by $53.68 \%$ and in 2007 there was no significant data.6 National Survey in 2009 stated there is 921,000 caesarean section from $4,039,000$ childbirths or around $22,8 \%$ of all childbirths. ${ }^{1,3}$
Caesarean section is the delivery through an incision on uterine wall through the front wall of abdomen. It can also be defined as hysterotomia to give birth to a fetus from uterus. Caesarean section is a priority consideration because it can save the lives of both mother and baby. However, the caesarean section process is not a safer alternative because it requires special supervision of indications and post surgical care for cesarean section to prevent inappropriate supervision that will result in death. ${ }^{4,5}$

Anxiety is unreasonable fear and is not supported by the situation. When an individual feels anxious, he/she feels uncomfortable or afraid or may have a hunch even though he/she does not understand why the disruptive emotions occur. There is no object that can be identified as anxiety stimuli. Further definition stated that anxiety is an emotion and subjective experience of an individual that is communicated interpersonally, having its own strengths and difficult to be observed directly. ${ }^{6-10}$

The data was obtained from Regional General Hospital Sheikh Yusuf Gowa regarding normal and caesarean section childbirth from 2015 to 2017. Normal delivery in 2015 is 1,011 patients, in 2016 there is 1,143 patients, and in 2017 there is 558 patients. While 
caesarean birth in 2015 is 308 patients, in 2016 there is 250 caesarean childbirths, and in 2017 there is 443 caesarean childbirths. The number of patients indicate that there are a large number of caesarean childbirth every year. Based on the preliminary study at Regional General Hospital of Sheikh Yusuf Gowa, those who chose normal delivery are 1-2 patients and they experience anxiety symptoms, while caesarean is around 2-3 patients and most of them experience anxiety.

Further, the researcher is interested to conduct a research on "Classical Music Therapy Effectiveness on Anxiety Level of Casarean Section Mother at Sheikh Yusuf Gowa Regional General Hospital”.

\section{Material and Method}

\section{Research Design}

This research was quantitative. The method was PreExperimental uisng One Group Pre-Test - Post Test, as the measurement of anxiety before and after the administration of classical music therapy on caesarean mothers.

\section{Population and Sample}

There were 83 mothers who gave birth by caesarean section at Regional General Hospital of Sheikh Yusuf Gowa in 2019. Meanwhile, the sample was 30 people who met the sample criteria at Regional General Hospital of Sheikh Yusuf Gowa.

\section{Sampling Technique}

The technique was purposive sampling. The purposive sampling with inclusion criteria as follows:

1) Willing to be a respondent.

2) Inpartu mothers scheduled for caesarean

3) Primigravida mothers

Data Analysis

The data analysis to determine the effects of classical music therapy to reduce anxiety level on caesarean section mothers was Wilcoxon rank test with alpha $=$ 0.05 .

\section{RESULT AND DISCUSSION}

This research was conducted on caesarean section mothers in 2019 by using one group pre test and post test design pre experimental design involving 30 respondents, the results are as follows:

Table 1: Efectiveness of Classical Music Therapy on Reducing Anxiety Level of Caesarean Section Mothers at Regional General Hospital of Syekh Yusuf Gowa 2019

\begin{tabular}{|l|l|l|l|}
\hline Variable & F & P & $\boldsymbol{\alpha}$ \\
\cline { 1 - 2 } $\begin{array}{l}\text { Negative } \\
\text { Ranks }\end{array}$ & 30 & & \\
\cline { 1 - 2 } $\begin{array}{l}\text { Positive } \\
\text { Ranks }\end{array}$ & 0 & 0.000 & 0.05 \\
\cline { 1 - 2 } Ties & 0 & & \\
\cline { 1 - 2 } Total & 30 & & \\
\hline
\end{tabular}

Data source: Wilcoxon test

The table indicates that from the 30 respondents given the music therapy, all respondents experience a decrease in their anxiety levels. The results of nonparametric statistical tests analysis using Wilcoxon with a confidence level of $95 \%(\alpha=0.05)$, obtain p-value of 0,000 , therefore, it can be concluded that classical music therapy is effective to reduce anxiety levels of caesarean section mothers.

\section{Discussion}

Anxiety is a subjective and emotional aspect of an individual since it involves subjective unpleasant feelings and arising due to stress, fear of failure, insecurity and conflict that is usually experienced by patients when they will experience childbirth process.(11) (6) ( (12)

The decreased anxiety level by music therapy occurs because listening to music can activate cells in limbic system that is associated with emotional behavior and autonomic nerves. The limbic system is activated and the individual becomes relax. Trappe also stated that Mozart's classical music with a tempo of 60 seconds/ minute can activate the left hemisphere and right hemisphere of the brain. Both hemispheres are required to prepare music rhythm. Therefore, it will make someone become relax and comfortable after listening to classical music. Music evoked ${ }^{11,13}$ 
When a person listening to classical music (audio), the sound will travel through ear, vibrate the eardrum, then shake the fluid within ear and vibrate the hair cells in cochlea to further through the cochlear nerve to brain and create imagination in the right brain and left brain which will have an impact in the form of comfort and mood changes. Mood changes (feelings) caused by classical music can reach the left cerebral cortex area. ${ }^{14,15}$

The data analysis using Wilcoxon test obtained $\mathrm{p}$ value of 0,000 . It can be concluded that classical music therapy is effective to reduce anxiety level of caesarean section mothers at Regional General Hospital of Sheikh Yusuf Gowa. Based on the Research, from a total of 30 samples there are 25 respondents who experience severe anxiety levels before classical music therapy. After the classical music therapy these 25 respondents experience mild anxiety level. There are 3 respondents who experience mild anxiety level before classical music therapy and after given classical music therapy, those 3 respondents experience moderate anxiety level. There are 2 respondents who experience moderate anxiety level before given classical music therapy and after given classical music therapy, those 2 respondents do not experience anxiety at all.

The results of the research are relevant with the research conducted by Dian Novita regarding the effects of classical music therapy on postoperative pain in open reduction and internal fixation (orif) at Dr.H.Abdul Moelok Regional General Hospital in Lampung Province. It is a quasi experiment research and nonequivalent pretest-posttest with control group, sampling uses causative sampling. Further, the results of the study states there is a significant effect of music therapy to reduce level of pain in patients with postoperative ORIF $(p$-value $=0.000 ; \alpha=0.05) .{ }^{16,17}$

The results of the research is also relevant with Farhaatun Hayati's research on the effects of classical music therapy on anxiety levels of menopausal women in Pisangan region, Eastern Ciputat, Southern Tangerang. This study used a pre-experiment method with one group pre-post test design. The result indicates there is an effect of classical music therapy to the anxiety level of menopausal women with a value $(p=0.000) .{ }^{16-19}$

The anxiety experienced by respondents are also differed from one another. It is because each respondent has a different psychological state so, they have different attitudes in coping with any changes. So, one of the therapy to be used is music. Music can increase creativity, build self-confidence, develop social skills, and improve motor skills, perception, and psychomotor development. It can also be used as a therapy for various needs, such as substituting depressant drugs for those who will face a surgery at the hospital. 17,20-24.

This is relevant with Djohan who explains that music therapy aims to help expressing feelings, assist physical rehabilitation, give a positive effect on mood and emotional condition, improve memory, and provide a unique opportunity to interact and build emotional closeness. Therefore, music therapy can also help to deal with stress, prevent illness and reduce pain. ${ }^{15}$

The selection of classical music therapy is relevant to music characteristic that is non-dramatic, dynamically predictable, soft, harmonious tone and without lyrics at a tempo of 60-80 bpm (beat per minute). Therefore, it is expected that listening to Mozart's classical music therapy can help reduce anxiety in inpartu mothers for caesarean $^{14}$

The researcher concludes that the anxiety of mothers decrease after Mozart's classical music therapy, Sonata for Two Pianos in Major, Type 448. It occurs because classical music which has alpha and tetha frequency categories of 5,000-8,000 $\mathrm{Hz}$ can stimulate the body and mind to be relax so, it stimulates the brain to produce serotonin and endorphin hormones to make the body relax and make the heart rate stable. Serotonin is a chemical substance that transmits nerve impulses throughout the space between nerve cells or neurons and has a role to prevent anxiety, vomiting and migraines. Changes of serotonin level into melatonin hormone has a regulatory effect on relaxation, so it can improve mood, create a calm, relaxed, safe, or pleasant atmosphere to make patients feel comfortable $\mathrm{e}^{9,14}$.

\section{Conclusion}

Based on the results and discussion in the previous chapter, it can be concluded that: Classical music therapy is effective to reduce anxiety of caesarean section mother at Syekh Yusuf Gowa Regional General Hospital.

Acknowledgement: The researcher would like to 
thank the Rector of Makassar Megarezky University and the director of Sheikh Yusuf Gowa Regional General Hospital for his assistance throughout the study.

Ethical Clearance: obtained form university ethical committee

\section{Conflict of Interest : None}

\section{Source of Funding : Self}

\section{References}

1. Hapsari DI, Hendraningsih T. Determinants of Sectio Caesarea Actions in Maternity at Ade Muhammad Djoen Hospital, Sintang District. jumantik Univ Muhammadiyah Pontianak. 2018;

2. Preterm P. Jurnal midwifery. 2019;1(1):1-14.

3. Gibbons L. The Global Numbers and Costs of Additionally Needed and Unnecessary Caesarean Sections Performed per Year: Overuse as a Barrier to Universal Coverage Mario Merialdi and Fernando Althabe World Health Report ( 2010 ) The path to universal coverage. 2010;(December 2014).

4. Vejnović TR, Costa SD, Ignatov A. New technique for caesarean section. Geburtshilfe Frauenheilkd. 2012;72(9):840-5.

5. Hofmeyr GJ, Mathai M, Shah AN, Novikova N. Techniques for caesarean section. Cochrane Database Syst Rev. 2008;(1).

6. Rowe $\mathrm{AD}$, Fitness J. Understanding the role of negative emotions in adult learning and achievement: A social functional perspective. Behav Sci (Basel). 2018;8(2).

7. Bystritsky A, Khalsa SS, Cameron ME, Schiffman J. Current diagnosis and treatment of anxiety disorders. P T. 2013;38(1):30-44.

8. Sudirman J, Sinrang AW, Marwang S, Nurlaily A, Sabar S, Astuti AT, et al. The analysis estradiol levels against sexual desire in perimenopause women in Makassar, South Sulawesi, Indonesia. Enferm Clin [Internet]. 2020;30:350-3. Available from: https://doi.org/10.1016/j.enfcli.2019.07.117

9. Stuckey HL, Nobel J. The connection between art, healing, and public health: A review of current literature. Am J Public Health. 2010;100(2):25463.

10. Sabar S, Lestari A, Ningsih JF. Correlation Between
Nutrition Status and Lipid Profile Toward Sexual Satisfaction on Perimenopause Women in Working Area Public Health Centre ( PHC ) of Bara-Baraya. 2020;564(3).

11. Sihombing N, Saptarini I, Putri DSK. The Determinants of Sectio Caesarea Labor in Indonesia ( Further Analysis of Riskesdas 2013). J Kesehat Reproduksi [Internet]. 2017;8(1):63-75. Available from: http://ejournal.litbang.depkes.go.id/index. php/kespro/article/view/6641/pdf_2

12. Jenkins TA, Nguyen JCD, Polglaze KE, Bertrand PP. Influence of tryptophan and serotonin on mood and cognition with a possible role of the gut-brain axis. Nutrients. 2016;8(1):1-15.

13. Cori L. Pelletier, MM M-B. The effect of music on decreasing arousal due to stress: a meta-analysis. J Music Ther. 2004;41(3):192-214.

14. Schaefer HE. Music-evoked emotions-Current studies. Front Neurosci. 2017;11(NOV):1-27.

15. Supervisor E, Review L. Music Therapy as an Intervention for Pain Perception Rachael Finnerty. 2000;(May 2004).

16. Тузиков ФВ, Рагино ЮИ, Тузикова НЛ, Иванова МВ, Талимов РВ, Никитин ЮП. Ф.В. Тузиков2, Ю.И. Рагино1, Нл. Тузикова2, М.В. Иванова1, Р.В. Талимов2, Ю.П. Никитин1. IEEE Int Conf Acoust Speech, Signal Process 2017. 2017;41(2):84-93.

17. Orpana H, Vachon J, Pearson C, Elliott K, Smith M, Branchard B. Correlates of well-being among Canadians with mood and/or anxiety disorders. Heal Promot Chronic Dis Prev Canada. 2016;36(12):302-13.

18. Tobing D. Terapi Musik Klasik. 2012;(X):918. Available from: repository.usu.ac.id/ bitstream/123456789/47147/4/Chapter II.pdf

19. Terapi P, Terhadap M, Nyeri I, Kala P, Aktif F, Keluarga K, et al. Pengaruh Terapi Musik Terhadap Intensitas Nyeri Persalinan Kala 1 Fase Aktif di Klinik Keluarga Pisangan Baru Kelurahan Pisangan Baru Kecamatan Matraman Jakarta Timur... 2016;6733-44.

20. Yazon AD, Ang-Manaig K, Tesoro JFB. Coping Mechanism and Academic Performance Among Filipino Undergraduate Students. KnE Soc Sci. 2018;3(6):30.

21. Sudirman J, Sampara N, Mawang S, Passe R, Aswan R, Ahmad M. The analysis of reducing 
blood glucose levels of diabetics with diabetes mellitus by giving a secang wood stew ( Caesalpinia sappan L .) to menopausal women in Makassar City ๕. Enfermería Clínica [Internet]. 2020;30:5069. Available from: https://doi.org/10.1016/j. enfcli.2019.07.148

22. Syam A, et al. The effect of pumpkin seed flour ( Cucurbita moschata Durch) on zinc serum levels in malnourished Wistar rats. Enferm Clin. 2020. https://doi.org/10.1016/j.enfcli.2019.10.095
23. Mallongi A, et al. Potential ecological risks of mercury contamination along communities area in tonasa cement industry Pangkep, Indonesia. Enferm Clin. 2020. https://doi.org/10.1016/j. enfcli.2019.10.054

24. Moore KS. A systematic review on the neural effects of music on emotion regulation: Implications for music therapy practice. J Music Ther. 2013;50(3):198-242. 